\title{
KAKVU NARODNU KNJIŽNICU ŽELIMO? ISTRAŽIVANJE KORISNIKA KNJIŽNICE I ČITAONICE BOGDANA OGRIZOVIĆA
}

\author{
WHAT KIND OF PUBLIC LIBRARY DO WE WANT? \\ THE RESEARCH OF THE USERS OF THE LIBRARY \\ AND READING ROOM BOGDAN OGRIZOVIĆ
}

\author{
Radovan Vrana \\ Odsjek za informacijske i komunikacijske znanosti, \\ Filozofski fakultet, Sveučilište u Zagrebu \\ rvrana@ffzg.hr \\ Jasna Kovačević \\ Knjižnice grada Zagreba \\ Jasna.Kovacevic@kgz.hr
}

UDK / UDC 027(497.5 Zagreb)

Izvorni znanstveni rad / Original scientific paper

Primljeno / Received: 2. 11. 2018.

Prihvaćeno / Accepted: 8. 1. 2019.

\section{Sažetak}

Cilj. Cilj istraživanja provedenog za potrebe ovog rada bio je utvrditi jake i slabe točke u radu Knjižnice i čitaonice Bogdana Ogrizovića (Knjižnice grada Zagreba) u cjelokupnom spektru radnih aktivnosti navedene knjižnice, s posebnim naglaskom na aktivnostima koje korisnici najviše percipiraju kao važne, poput korisničkih usluga, građe, prostora, informacijske i komunikacijske tehnologije, zaposlenika u knjižnici, opreme, rasvjete, atmosfere za rad u knjižnici itd.

Pristup/metodologija/dizajn. U provedbi istraživanja upotrijebljena je metoda ankete. Anketni upitnik sastojao se od dva dijela. U prvom otvorenom dijelu ispitanicima

Vjesnik bibliotekara Hrvatske 61, 2(2018), 47-71

ISSN 0507-1925

(C) VBH 2018. 
je pružena mogućnost samostalnog upisa triju želja o bilo čemu što bi željeli vidjeti ili u čemu bi željeli sudjelovati u knjižnici. Drugi dio anketnog istraživanja sastojao se od sedam pitanja zatvorenog tipa uz mogućnost samostalnog dodavanja odgovora u tri pitanja. U istraživanju je upotrijebljen prigodni uzorak ispitanika.

Rezultati. Rezultati istraživanja potvrdili su postojanje problema poput nedostatka prostora i smanjene mogućnosti nabave najnovijih naslova građe u dovoljnom broju za sve zainteresirane korisnike, što pak ovisi o financijskim mogućnostima knjižnice. Rezultati istraživanja pokazali su i želje korisnika za pristupom e-građi i uslugama knjižnice putem interneta te želju za još raznovrsnijim knjižničnim aktivnostima, premda je knjižnica u istraživanju u velikoj mjeri prepoznata kao brend upravo na temelju već ionako velikog broja aktivnosti koje se u njoj odvijaju. Navedeni problemi ujedno su i sustavni problemi koje knjižnica nije u mogućnosti samostalno riješiti bez dodatne podrške knjižničnog sustava u kojem se nalazi.

Praktična primjena. Rezultate istraživanja moguće je primijeniti u procesu poboljšavanja postojećih te oblikovanja budućih knjižničnih usluga i aktivnosti s ciljem postizanja još većeg zadovoljstva korisnika.

Ključne riječi: istraživanje korisnika, narodne knjižnice, vrednovanje usluga narodnih knjižnica

\begin{abstract}
Purpose. The aim of the research was to collect data about the strong and weak points in operation of the Bogdan Ogrizović public library (Zagreb City Libraries network). The research included all library activities that are most frequently perceived by the library users as the most important, such as library services, library materials, library space, ICT support, library staff, equipment, lights, work atmosphere, etc.
\end{abstract}

Approach/methodology/design. The survey was used as the principal method of research. It was divided into two parts. The first part aimed at the users' expressing three wishes about what they would like to have in the library or about activities they would like to participate at. The second part consisted of seven questions (a combination of the closed and open type questions, with a possibility of adding their own responses to three of the seven questions). A convenience sample was used as a sampling method in the research.

Findings. The research results have revealed the long-standing problems, like the lack of library space and the restricted acquisition of library materials due to financial restrictions of the library budget. The results also indicated the wishes of the library users for accessing the e-content and online library services as well as the wishes for a larger number and more versatile activities in the library. The library was also recognized as a brand precisely because of the many popular activities taking place in its premises. The 
problems confirmed in this research are the systemic problems, which could be solved only by a more intensive support from the library network this library belongs to.

Practical implications. The results of the research are applicable for making improvements in the existing library services and in the process of designing future library services in order to achieve even better results in user satisfaction with library services.

Keywords: evaluation of public library services, public libraries, user studies

\section{Uvod}

Narodna knjižnica ima posebno mjesto u društvu. Ona je mjesto susreta, učenja, zabave, komuniciranja, razmjene znanja i iskustava i otvaranja novih vidika. U očima društva ona je vrijedan javni resurs koji utječe na dobrobit i razvoj pojedinaca i zajednica. Premda osnivači narodnih knjižnica na raspolaganju imaju sve skromnija sredstva za financiranje svoga rada, narodne knjižnice svojim se projektima i programima uzdižu iznad tih ograničenja te vlastitim naporima široj društvenoj zajednici ukazuju na svoju kvalitetu i sposobnost stvaranja raznolike ponude građe i usluga. Bez obzira na neprekidne napore koje narodne knjižnice ulažu u izgradnju svojih fondova i oblikovanje i provedbu svojih usluga te u stvaranje pozitivne slike o knjižnicama u društvu, različite društvene skupine različito ih promatraju i imaju različitu percepciju o njihovoj vrijednosti u društvu, a koja nije uvijek pozitivna jer se knjižnice percipiraju kao trošak. Zbog toga knjižnice moraju voditi brigu o svojem utjecaju na društvo i maksimalizirati učinkovitost pružanja svojih usluga danas i u budućnosti temeljeći svoje planove razvoja na rezultatima istraživanja svojih korisnika o percepciji knjižnice s ciljem što bolje brige o dodijeljenim resursima i načinima njihove upotrebe u knjižnici. ${ }^{1}$

Dosadašnja istraživanja ${ }^{2}$ provedena u Knjižnici i čitaonici Bogdana Ogrizovića (Knjižnice grada Zagreba) u samom srcu Zagreba pokazala su postojanje pozitivne percepcije među njezinim korisnicima o toj narodnoj knjižnici. Istraživanja su potvrdila njezinu važnu ulogu huba pojedinaca i zajednica u društvu s jedne strane te skupa pouzdanih i kvalitetnih usluga u svijetu ograničenih resursa i mogućnosti

1 Usp. Henczel, S. Measuring and evaluating the library's contribution to organisational success:developing a strategic measurement model. // Performance Measurement and Metrics 7, 1(2006),str. 7.

2 Usp. Vrana, R.; J. Kovačević. Položaj knjižnice u umreženom društvu. // Vjesnik bibliotekara Hrvatske 53, 3-4(2010), 25-41; Vrana, R.; J. Kovačević, J. Percepcija korisnika o knjižnici i knjižničnim uslugama kao temelj marketinške strategije knjižnice. // Vjesnik bibliotekara Hrvatske 56, 3(2013), 23-46; Vrana, R.; J. Kovačević Pogled na knjižnične usluge iz perspektive korisnika. // Vjesnik bibliotekara Hrvatske 58, 1-2(2015), 135-160; Vrana, R.; J. Kovačević, J. Razvoj knjižničnih zbirki kao preduvjet i mjera razvoja knjižnice. // Vjesnik bibliotekara Hrvatske 60, 1(2017), 79-102; te, Vrana, R.; J. Kovačević. Istraživanje korisnika u knjižnicama: temelj razvoja knjižnica. // Svezak: časopis Društva knjižničara Bilogore, Podravine i Kalničkog prigorja $17(2015), 9$. 
s druge strane. Imajući na umu primjer te izvrsne narodne knjižnice, druge narodne knjižnice u Hrvatskoj ne bi trebale odustati od svojih vizija budućnosti, želja i planova za unapređivanje svojih usluga kako bi što bolje odgovorile na buduće izazove i potrebe za ostvarenjem jednakih mogućnosti za sve u pristupu znanju i omogućavanju obrazovanja korisnika te zadovoljavanju njihovih informacijskih, kulturnih i drugih potreba. Takav pristup stvaranju pozitivnog ozračja u knjižnicama potreban je za oblikovanje brenda narodnih knjižnica. Ovaj rad stoga ima za cilj ustanoviti jake i slabe točke u radu Knjižnice i čitaonice Bogdana Ogrizovića (Knjižnice grada Zagreba) u cjelokupnom spektru njezinih radnih aktivnosti, s posebnim naglaskom na aktivnostima koje korisnici najviše percipiraju, sa svrhom sudjelovanja korisnika u oblikovanju planova razvoja knjižnice kao nadgradnji službenih vizija i agendi.

\section{Narodne knjižnice i promjene}

Glavni pokretač promjena u narodnim knjižnicama jest prisutnost i rast umreženog svijeta koji mijenja percepciju korisnika o knjižnicama i građi te uslugama koje bi knjižnice trebale ponuditi svojoj korisničkoj zajednici. U proteklih nekoliko desetljeća informacijska i komunikacijska tehnologija imala je značajnu ulogu u razvoju narodnih knjižnica, pa je za očekivati da će taj trend biti nastavljen. Voditelji knjižnica zbog toga svakodnevno traže rješenja kako bi se ponudile usluge temeljene na informacijskoj i komunikacijskoj tehnologiji i omogućilo da se takve usluge odvijaju neometano s obzirom na postojeću i dostupnu tehnološku infrastrukturu ${ }^{3}$, ali i ograničene financijske i druge resurse knjižnice. Time se nastoji odgovoriti na zahtjeve korisnika za novim uslugama i građom, jer brojne promjene u knjižnicama ne pokreće samo razvoj informacijske i komunikacijske tehnologije nego ih pokreću i sami korisnici knjižnice (npr. nove usluge za posebne kategorije korisnika knjižnice). ${ }^{4}$

Povezanost knjižnica s informacijskom i komunikacijskom tehnologijom često se spominje uz pojam knjižnice 2.0 koju je moguće definirati kao model moderniziranog oblika knjižničnih usluga i načina na koje su te usluge ponuđene korisnicima. Takve usluge uključuju povećani dotok informacija od korisnika natrag prema knjižnici. ${ }^{5}$ Taj je koncept važan jer je promijenio odnos između knjižnice i korisnika čija se uloga promijenila iz uloge konzumenta u ulogu stvaratelja informacija. U knjižnici 2.0 knjižničar nije samo pružatelj pristupa informacijama nego je

\footnotetext{
3 Usp. Cheryl S.; K. Roberts; K. Haycock. The role of influence in city and public library partnerships: an exploratory study. // Library Management 35, 3(2014), str. 213-214.

4 Usp. Rowley, J. Should your library have an innovation strategy?. // Library Management 32, 4/5(2011), str. 251.

5 Usp. Ahmad, Z. Library 2.0: the 21st century Web based library services. // Gyankosh: The Journal of Library \& Information Management 4, 2(2013), str. 29.
} 
ujedno odgovoran i za nastanak sadržaja. Korisnici također stvaraju sadržaj u međusobnoj interakciji, ali i u interakciji s knjižničarom. ${ }^{6}$ Usto, korisnici danas mogu lakše doći do informacija dostupnih putem interneta uz male ili nikakve troškove, dok su u ranijim razdobljima informacije morale biti odabrane, kupljene/nabavljene, pohranjene i diseminirane, čime su se bavili informacijski stručnjaci. ${ }^{7}$ Narodne knjižnice već barem 10 godina u ponudu svojih usluga uključuju i pristup internetu, a sve češće i vlastite usluge dostupne putem interneta. Premda se može učiniti da je u 2018. godini pomalo deplasirano istraživati odnos korisnika i knjižnice prema internetskim uslugama dostupnim putem interneta, mišljenja smo da je taj odnos potrebno iznova preispitivati. Razlozi za to jesu već spomenute promjene u sferi razvoja tehnologija koje se upotrebljavaju prilikom interakcije korisnika s knjižnicom te u samoj knjižnici, ali i promjene koje sami korisnici doživljavaju u vlastitim stavovima i ponašanjima povezanim $\mathrm{s}$ upotrebom informacijskih izvora i informacijske i komunikacijske tehnologije u svojem svakodnevnom životu. Ishod tih promjena utječe na samoga korisnika, ali i na knjižnicu (ukoliko je ona dio komunikacijske okoline korisnika).

Korisnici knjižnica usvajaju i nove oblike ponašanja koje donose u knjižnicu, a za koje vjeruju kako ih vode prema uspjehu u njihovu životu. Knjižnice stoga moraju držati korak i biti informirane o tome koje su promijenjene potrebe korisnika i što njihovi korisnici rade $u$ informacijskoj okolini poput interneta, a nepoznavanje tih činjenica knjižnice ograničava u proaktivnom razvoju novih usluga i ponudi novih informacijskih izvora. ${ }^{8}$ Zbog toga knjižnice moraju razumjeti nove oblike ponašanja korisnika potaknute promjenama u društvu i upotrebom informacijske i komunikacijske tehnologije umjesto da se oslanjaju na normirane, idealizirane i zastarjele pretpostavke. ${ }^{9}$ Nadalje, knjižnice vrlo često nastoje zadovoljiti najširi spektar informacijskih potreba svojih korisnika, jer su prema vlastitim definicijama otvorene svim društvenim grupama. U sadašnjem vremenu, koje je izrazito obilježeno utjecajem informacijske i komunikacijske tehnologije na živote korisnika, oni od knjižnica traže usluge prilagođene njima, tj. pojedincima, uz pristup tehnologiji i građi 24 sata dnevno. ${ }^{10}$ Pritom se postavlja pitanje razumijevanja potreba različitih grupa korisnika s posebnim zahtjevima u usporedbi sa zadovoljavanjem širokog spektra zahtjeva, a što knjižnicama pomaže u stvaranju usluga koje će biti prilagođene zadovoljavanju specifičnih potreba korisnika. ${ }^{11}$

\footnotetext{
6 Isto, str. 28.

7 Usp. Henczel, S. Navedeno djelo, str. 8.

8 Isto, str. 9.

9 Usp. Proffitt, M.; J. Michalko; M. Renspie. Shaping the library to the life of the users: adapting, empowering, partnering, engaging. Dublin, Ohio: OCLC, 2015. Str 4.

10 Usp. Haycock, K. Exemplary public library branch managers: their characteristics and effectiveness. // Library Management 32, 4/5(2011), str. 266.

11 Usp. Proffitt, M.; J. Michalko; M. Renspie. Navedeno djelo, str 6.
} 
Kako bi stvaranje novih i unapređivanje postojećih usluga bilo uspješno, potrebno je kontinuirano provoditi istraživanja korisnika o njihovu zadovoljstvu različitim aspektima rada knjižnica. Zadovoljstvo korisnika uslugama knjižnice povezano je s kvalitetom njihova pružanja, a mjerenje tog zadovoljstva može pomoći knjižnici u postizanju postojećih standarda usluga i utvrđivanju odgovara li pružanje usluga očekivanjima koja korisnici imaju od knjižnice. ${ }^{12} \mathrm{U}$ tu svrhu u svijetu knjižnica upotrebljavale su se i upotrebljavaju se različite metode i različiti alati kao što su LibQUAL+ (kojim se istražuje zadovoljstvo korisnika knjižnicom, a uz to služi za otkrivanje razine zadovoljstva korisnika koju je moguće usporediti s percipiranom razinom usluge, minimalnom i poželjnom razinom, kao i s drugim knjižnicama ${ }^{13}$ ), rudarenje podataka uz primjenu statističkih metoda, testiranje uporabljivosti, anketni upitnici koje su oblikovale same knjižnice (kojima je također moguće mjeriti zadovoljstvo korisnika knjižnicom i percipiranu kvalitetu usluga knjižnica te provoditi dugoročne usporedbe s indikatorima za poboljšavanje knjižničnih usluga ${ }^{14}$ ), analize poslovnih procesa te studija prostora i usluga knjižnica. ${ }^{15}$ S obzirom na povezanost narodnih knjižnica s informacijskom i komunikacijskom tehnologijom u provedbi njihovih usluga novijeg datuma, u knjižnicama su uvedena i testiranja uporabljivosti. Riječ je o jednom od novijih alata kojim se najčešće mjeri učinkovita upotreba elektroničkih informacijskih izvora. ${ }^{16}$

A što se pojedinim metodama i alatima istražuje, osim već navedenog zadovoljstva radom knjižnice? Prostor u knjižnici gotovo je najvažniji segment rada knjižnice, pri čemu se često pojavljuje problem njegove ograničenosti. U svojem radu o knjižničnom prostoru u 21. stoljeću Seal je naglasio kako postojeća literatura o knjižnicama objavljena u 20. stoljeću odražava razmišljanja prema kojima knjižnični prostor moraju oblikovati knjižničari i on mora služiti knjižničarima, dok su korisničke potrebe bile u drugom planu. ${ }^{17}$ Seal se također osvrnuo na rad Rogersa i Webera u kojem je jasno navedeno što korisnici očekuju od knjižnice: ugodnu okolinu, ugodnu rasvjetu koja nije prejaka, ugodne boje, adekvatnu ventilaciju, ugodnu temperaturu prostora, blokiranje zvuka kako čitatelje ne bi smetale druge aktivnosti, stolice i radne površine koje omogućavaju dugu i često intenziv-

12 Usp. Urquhart, C.; J. Turner. Reflections on the value and impact of library and information services. Part 2: impact assessment. // Performance Measurement and Metrics 17, 1(2016), str. 6.

13 Usp. Hiller, S.; M. Kyrillidou; J. Self. When the evidence is not enough: organizational factors that influence effective and successful library assessment. // Performance Measurement and Metrics 9, 3(2008), str. 226.

14 Isto, str. 226.

15 Isto, str. 225.

16 Isto, str. 226.

17 Usp. Rogers, R. D.; D. C. Weber. University library administration, New York : H.W. Wilson Company, 1971. Citirano prema: Seal, R. A. Library spaces in the 21 st century: meeting the challenges of user needs for information, technology, and expertise. // Library Management 36, 8/9(2015), str. 559. 
nu koncentraciju. ${ }^{18}$ Podbrežnik je proveo istraživanje u jednoj narodnoj knjižnici u Sloveniji (čiji naziv nije naveden) te je zaključio kako korisnici nisu imali visoka očekivanja u odnosu na vanjski izgled zgrade knjižnice i njezine okolice, unutrašnji prostor, opremu knjižnice, osoblje i promocijske materijale, no istraživanje je pokazalo da su (niska) očekivanja korisnika povezana s navedenim elementima rada knjižnice bila premašena u pozitivnom smislu. Korisnicima su usto bili važni pouzdana i sigurna upotreba usluga, povjerenje u osoblje knjižnice koje mora biti osposobljeno za svoj rad i njegov odziv na upite, dok im je nešto manje važna bila pažnja koju je osoblje posvećivalo svakom pojedinom korisniku. ${ }^{19}$ Upravo je interakcija knjižničara s korisnicima važna u istraživanjima korisnika. Knjižnice se temelje na radu knjižničara koji se trude osigurati dobre usluge za korisnike te žele raditi s ljudima i biti im od pomoći. ${ }^{20} \mathrm{Uz}$ prostor, usluge i knjižničare, korisnike knjižnica zanima i građa.

Premda korisnici zasigurno žele da dio knjižničnog fonda bude dostupan u elektroničkom obliku, narodne knjižnice u Hrvatskoj svoje fondove još uvijek najvećim dijelom temelje na tiskanoj građi, uz mali udio elektroničke građe. Stoga su problemi pristupa tiskanoj građi zbog premalog broja primjeraka ili nepostojanja nekih naslova ujedno i primarni problemi s kojima se korisnici knjižnica susreću, s obzirom na to da je posudba knjiga njihova najomiljenija aktivnost u knjižnici. Nepostojeći naslovi odnose se i na elektroničku građu koju bi korisnici također htjeli pronaći u knjižnici. U njezinu nedostatku korisnici vrlo često izravno pristupaju nekom komercijalnom izvoru informacija putem interneta i izvan knjižnice te tako zadovoljavaju svoju ad hoc stvorenu potrebu za informacijama i na taj način možda kupuju irelevantnu i neprimjerenu informaciju jer nisu upoznati s kvalitetom elektroničkih izvora informacija koje nudi knjižnica. ${ }^{21}$ Općenito, zbog važnosti građe i njezine povezanosti s ponuđenim uslugama i taj je dio funkcioniranja knjižnice uvršten u istraživanje.

Prikupljanje podataka putem istraživanja važno je za učinkovito i konzistentno planiranje i odlučivanje u knjižnicama. ${ }^{22}$ Podaci prikupljeni istraživanjima korisnika mogu se upotrijebiti za ispitivanje učinkovitosti sljedećeg niza aktivnosti u knjižnicama: pregleda knjižnične statistike, oblikovanja organizacijske strukture knjižnice, utvrđivanja koji su dijelovi knjižnice funkcionirali dobro, utvrđivanja problema u radu knjižnice, pronalaženja posebnih područja u knjižnicama koja je potrebno vrednovati te ispitivanja očekivanja same knjižnice vezanih uz vlastiti razvoj. ${ }^{23}$

\footnotetext{
18 Isto, str. 559.

19 Usp. Podbrežnik, I. Ugotavljanje zadovoljstva uporabnikov s kakovostjo storitev v slovenski splošni knjižnici. // Knjižnica 60, 1(2016), str. 40-41.

20 Isto, str. 18.

21 Usp. Henczel, S. Navedeno djelo, str. 9.

22 Usp. Hiller, S.; M. Kyrillidou; J. Self. Navedeno djelo, str. 223.

23 Isto, str. 224.
} 


\section{Istraživanje korisnika Knjižnice i čitaonice Bogdana Ogrizovića}

\subsection{Metodologija istraživanja i određivanje uzorka ispitanika}

Istraživanja korisnika uobičajena su i redovita aktivnost u knjižnicama. Kao što je navedeno u uvodnom dijelu rada, za potrebe istraživanja korisnika moguće je upotrijebiti različite postojeće metode i alate, stvoriti nove ili pak kombinirati prve i druge. Cilj istraživanja korisnika jest utvrditi postojanje jakih i slabih točaka u radu Knjižnice i čitaonice Bogdana Ogrizovića (Knjižnice grada Zagreba) u cjelokupnom spektru radnih aktivnosti navedene knjižnice, uključujući i aktivnosti knjižnice koje korisnici najviše percipiraju kao važne, poput korisničkih usluga, građe, prostora, informacijske i komunikacijske tehnologije, zaposlenika u knjižnici, opreme, rasvjete, atmosfere za rad u knjižnici itd. Samo kontinuirano istraživanje korisnika knjižnice može dati kvalitetnu i cjelovitu sliku o samoj knjižnici i omogućiti vodstvu knjižnice donošenje ispravnih odluka o radu knjižnice. Dosadašnja istraživanja korisnika narodne Knjižnice i čitaonice Bogdana Ogrizovića ${ }^{24}$ pokazala su visok stupanj motivacije zaposlenika navedene knjižnice, ali i korisnika, za sudjelovanje u istraživanju koje je za cilj imalo prikupiti podatke koji će unaprijediti rad knjižnice. Istraživanje korisnika u ovom radu također je usmjereno prema segmentima rada knjižnice koje korisnici najlakše prepoznaju i koji predstavljaju ključne segmente rada narodne knjižnice koji imaju utjecaj na zadovoljstvo samih korisnika.

Anketno istraživanje uz pomoć upitnika odabrano je za glavnu metodu istraživanja. Ta istraživačka metoda ima određenih nedostataka, ali je ujedno i najjeftinija metoda za masovno istraživanje ispitanika, lako ju je prilagoditi ciljevima istraživanja i, ništa manje važno, riječ je o metodi koju ispitanici prepoznaju i voljni su sudjelovati u njezinoj realizaciji. U ovom istraživanju anketni upitnik podijeljen je na dva velika dijela. U prvom, otvorenom dijelu ispitanicima je pružena mogućnost samostalnog upisa triju želja o bilo čemu što bi željeli vidjeti ili u čemu bi željeli sudjelovati u knjižnici. Umjesto dosadašnje prakse definiranja svih odgovora unaprijed u zatvorenom dijelu istraživanja, uz poneku iznimku i mogućnost dopisivanja odgovora za koje korisnici smatraju da ih je potrebno dopisati, u prvom je dijelu istraživanja korisnicima ponuđena potpuna sloboda u ispisivanju odgovora koji su knjižnici vrlo važni za njezino stabilno djelovanje. Izborom potpuno otvorenog inicijalnog pitanja nakon kojeg je slijedilo 7 zatvorenih pitanja željelo se potaknuti korisnike knjižnice na što izravnije izražavanje njihovih želja (a time i njihovih potreba) povezanih s boravkom u knjižnici i pasivnim ili aktivnim sudjelovanjem u aktivnostima knjižnice. Na taj se način ispitanike nije ograničavalo na unaprijed predviđeni niz odgovora po segmentima rada knjižnice, već ih se željelo

24 Usp. Vrana, R.; J. Kovačević, J. Položaj. Navedeno djelo.; Vrana, R.; J. Kovačević. Percepcija. Navedeno djelo.; Vrana, R.; J. Kovačević. Pogled. Navedeno djelo.; Vrana, R.; J. Kovačević. Razvoj. Navedeno djelo.; Vrana, R.; J. Kovačević. Istraživanje. Navedeno djelo. 
potaknuti na aktivno i izravno sudjelovanje u oblikovanju budućnosti knjižnice. Drugi dio anketnog istraživanja sastojao se od sedam pitanja zatvorenog tipa uz mogućnost samostalnog dodavanja odgovora u tri pitanja. U istraživanju je upotrijebljen prigodni uzorak ispitanika jer zbog nedostatka mogućnosti identificiranja ispitanika prilikom ulaska u knjižnicu i njihove selekcije na temelju demografskih, obrazovnih i drugih kriterija nije bilo moguće primijeniti drugi način određivanja uzorka ispitanika. Istraživanje je provedeno u prostoru Knjižnice i čitaonice Bogdana Ogrizovića (Knjižnice grada Zagreba) u razdoblju od 10. srpnja do 28. rujna 2018. godine. U navedenom su razdoblju prikupljena 63 popunjena anketna upitnika. Broj popunjenih upitnika može, ali i ne mora biti indikativan kada je u pitanju istraživanje korisnika narodnih knjižnica poput ove. U istraživanju su sudjelovali svi korisnici knjižnice koji su se tijekom provedbe istraživanja zatekli u Knjižnici i čitaonici Bogdana Ogrizovića i koji su željeli sudjelovati u istraživanju. Potrebno je naglasiti da je istraživanje provedeno u ljetnom razdoblju, kada je broj korisnika knjižnica općenito manji i kada se korisnici knjižnica posvećuju nekim drugim aktivnostima izvan knjižnica. Vjerujemo da bi istraživanje provedeno u nekom drugom dijelu godine privuklo veći broj ispitanika.

\subsection{Rezultati istraživanja korisnika}

Prvo pitanja ankete odnosilo se na mogućnost upisivanja triju korisničkih želja o bilo čemu što bi željeli vidjeti ili u čemu bi željeli sudjelovati u knjižnici. Odgovori ispitanika podijeljeni su u nekoliko skupina prema svojoj srodnosti: prostor, navigacija prostorom, radno vrijeme, usluge, građa, buka, kvaliteta zraka, informacijska i komunikacijska tehnologija, aktivnosti i ostalo. U svakoj od navedenih kategorija ispitanici su bili u mogućnosti posve slobodno izraziti svoje želje za bilo kojim predmetom, aktivnošću, uslugom i sl. koji prema njihovu mišljenju u ovom trenutku nedostaju knjižnici ili ih je potrebno unaprijediti. Odgovori ispitanika (prilog 1) većim su dijelom očekivani jer su i u ranijim istraživanjima ${ }^{25}$ korisnici ove knjižnice često naglašavali nedostatak prostora u knjižnici, nedostatak dnevnog svjetla, nedostatak posebno ograđenih prostora za pojedine grupe korisnika, nedostatak dodatnih oznaka prostora za bolje snalaženje u prostoru knjižnice, nedostatak e-građe i računala, predlagali su nove aktivnosti i sl. Najveći dio želja ispitanika u ovom istraživanju odnosio se na ograničenja prostora u kojem se nalazi knjižnica, kao i na financijska sredstva kojima je moguće oblikovati nove usluge i nabaviti dodatnu građu. Bez obzira na upoznatost knjižnice s navedenim problemima, neke od njih nije jednostavno riješiti jer ograničenost pojedinih resursa pomoću kojih knjižnica radi uopće nije moguće promijeniti (prostor) ili

25 Usp. Vrana, R.; J. Kovačević, J. Položaj. Navedeno djelo.; Vrana, R.; J. Kovačević. Percepcija. Navedeno djelo.; Vrana, R.; J. Kovačević. Pogled. Navedeno djelo.; Vrana, R.; J. Kovačević. Razvoj. Navedeno djelo.; Vrana, R.; J. Kovačević. Istraživanje. Navedeno djelo. 
ih je moguće promijeniti, ali u ograničenom opsegu (financijska sredstva). Nove usluge i građa novijeg datuma ostvarivi su ciljevi u skladu s godišnjim planovima knjižnice.

Drugi dio istraživanja sastojao se od sedam pitanja. Prvo od sedam pitanja pružilo je korisnicima mogućnost ocjenjivanja segmenata rada knjižnice prema percipiranoj važnosti. Uz svaki od 20 ponuđenih odgovora ispitanici su mogli upisati ocjenu od 1 (najmanje važno) do 5 (najvažnije) te su mogli označiti više odgovora. Nakon mogućnosti da samostalno napišu svoje želje bez utjecaja knjižničara ili ispitivača, ispitanicima je ponuđeno rangiranje segmenata rada knjižnice prema važnosti kao ju oni procjenjuju prilikom upotrebe knjižnice. Tablica 1 pokazuje sukladnost želja koje su ispitanici iskazali u prvom pitanju prvog dijela istraživanja i drugog dijela istraživanja s prioritetima koje su sami ispitanici odabrali, a potom i ocijenili nizom ocjena.

Tablica 1. Ocjenjivanje segmenata knjižnice prema njihovoj važnosti za korisnike knjižnice

\begin{tabular}{|l|c|c|c|c|c|}
\hline & $\mathbf{1}$ & $\mathbf{2}$ & $\mathbf{3}$ & $\mathbf{4}$ & $\mathbf{5}$ \\
\hline Tihi prostor za učenje & 1 & 0 & 4 & 4 & 28 \\
\hline Bežični pristup internetu (Wi-Fi) & 2 & 0 & 3 & 6 & 26 \\
\hline Izvori informacija potrebni za obrazovanje & 3 & 0 & 2 & 6 & 25 \\
\hline $\begin{array}{l}\text { Tihi prostor za čitanje novina i časopisa } \\
\text { (tiskanih i digitalnih) }\end{array}$ & 2 & 2 & 3 & 6 & 24 \\
\hline $\begin{array}{l}\text { Pomoć knjižničara u upotrebi bilo kojeg } \\
\text { segmenta rada knjižnice }\end{array}$ & 0 & 1 & 6 & 6 & 23 \\
\hline $\begin{array}{l}\text { Izvori informacija potrebni za znanstvena } \\
\text { istraživanja }\end{array}$ & 1 & 2 & 6 & 3 & 23 \\
\hline $\begin{array}{l}\text { Besplatno sudjelovanje u događajima koji } \\
\text { se odvijaju u knjižnici }\end{array}$ & 1 & 2 & 0 & 10 & 22 \\
\hline $\begin{array}{l}\text { Uspješna posudba knjiga svaki put (veći } \\
\text { broj primjeraka istoga naslova knjige) }\end{array}$ & 1 & 1 & 5 & 8 & 20 \\
\hline $\begin{array}{l}\text { Mrežna stranica knjižnice za interakciju } \\
\text { korisnika s knjižnicom }\end{array}$ & 1 & 3 & 4 & 7 & 20 \\
\hline $\begin{array}{l}\text { Posudba e-knjiga (putem mrežne stranice } \\
\text { knjižnice) }\end{array}$ & 3 & 3 & 7 & 5 & 18 \\
\hline
\end{tabular}




\begin{tabular}{|l|c|c|c|c|c|}
\hline & $\mathbf{1}$ & $\mathbf{2}$ & $\mathbf{3}$ & $\mathbf{4}$ & $\mathbf{5}$ \\
\hline $\begin{array}{l}\text { Mogućnost predlaganja novih naslova } \\
\text { knjiga, časopisa i novina knjižnici }\end{array}$ & 0 & 1 & 6 & 10 & 17 \\
\hline Aktivnosti za odrasle & 2 & 2 & 8 & 7 & 15 \\
\hline Besplatne (sve) usluge & 2 & 1 & 10 & 8 & 14 \\
\hline $\begin{array}{l}\text { Aplikacija za mobilni telefon za interakciju } \\
\text { korisnika s knjižnicom }\end{array}$ & 3 & 4 & 6 & 9 & 13 \\
\hline $\begin{array}{l}\text { Prilagođeno radno vrijeme- ljetno } \\
\text { (skraćeno/dvokratno) i zimsko (cijeli dan) }\end{array}$ & 3 & 4 & 8 & 8 & 12 \\
\hline Aktivnosti za tinejdžere & 2 & 4 & 11 & 5 & 12 \\
\hline $\begin{array}{l}\text { Izvori informacija potrebni za pronalaženje } \\
\text { posla }\end{array}$ & 6 & 6 & 3 & 11 & 11 \\
\hline Prostor za susrete & 4 & 4 & 9 & 8 & 11 \\
\hline Aktivnosti za djecu & 2 & 6 & 9 & 6 & 11 \\
\hline $\begin{array}{l}\text { Mogućnost predlaganja novih usluga } \\
\text { knjižnici }\end{array}$ & 2 & 3 & 5 & 14 & 10 \\
\hline
\end{tabular}

Odgovori na prvo pitanje ukazuju na aktualne probleme s kojima se Knjižnica i čitaonica Bogdana Ogrizovića suočava. Ispitanici su svoje odgovore rangirali sukladno vlastitim viđenjima knjižnice. Promatrano prema segmentima rada knjižnice, visok rang ostvario je segment prostora knjižnica, nakon toga korisnici žele što bolju internetsku infrastrukturu, pomoć knjižničara te što veću količinu informacijskih izvora potrebnih za različite svrhe. Sveukupno, ispitanici su visoko rangirali sve segmente knjižnice koje neposredno upotrebljavaju, što je bila svrha ovog pitanja.

Drugo od sedam pitanja odnosilo se na iskustvo korisnika u kontaktu s djelatnicima knjižnice, pri čemu su ispitanici mogli odabrati više ponuđenih odgovora. Ispitanicima je bilo ponuđeno pet odgovora i jedna mogućnost samostalnog dopisivanja odgovora. Ispitanici $(\mathrm{N}=63)$ su imali mogućnost odabira više odgovora. Prema rezultatima prikazanim na slici 1, ispitanici su pokazali visok stupanj pozitivnog iskustva u kontaktu s djelatnicima knjižnice. 


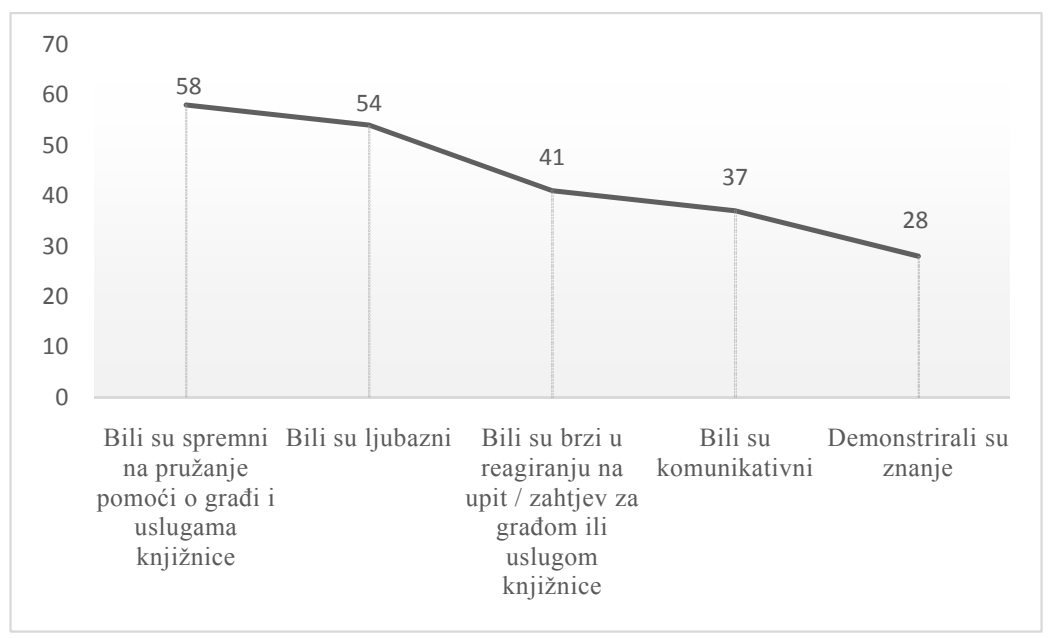

Slika 1. Iskustvo korisnika u kontaktu s djelatnicima knjižnice

Uz navedene odgovore ponuđena su još dva odgovora u otvorenom dijelu pitanja: „Doduše, kako koji“ i „U principu bez kontakta s djelatnicima“. Sveukupno, korisnici nemaju gotovo nikakvih zamjerki na osoblje knjižnice, što za knjižnice znači da imaju važan temelj i oslonac u planiranju svojih usluga i njihovoj provedbi.

Treće od sedam pitanja odnosilo se iskustvo korisnika $(\mathrm{N}=62)$ prilikom posudbe knjiga u knjižnici. Ispitanicima je bilo ponuđeno pet odgovora i jedna mogućnost samostalnog dopisivanja odgovora. Ispitanici su imali mogućnost odabira više odgovora.

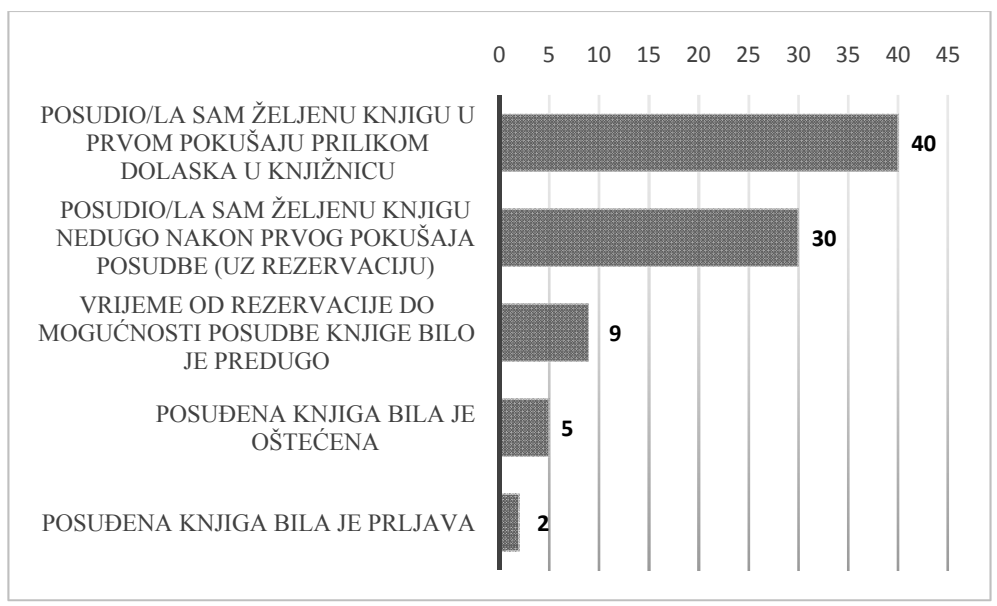

Slika 2. Iskustvo korisnika prilikom posudbe knjiga u knjižnici 
Dolazak do željene građe u narodnim knjižnicama uvijek predstavlja problem zbog nedostatka dovoljnog broja primjeraka nekog naslova u odnosu na želje i potrebe korisnika i nedostatak najnovijih naslova s tržišta, čemu knjižnice nastoje doskočiti odabirom najboljih novih naslova kako bi time zadovoljile želje i potrebe korisnika za određenom literaturom i ujedno osuvremenile fond novim naslovima. Odgovori na ovo pitanje sugeriraju da je najveći broj ispitanika već u prvom pokušaju prilikom dolaska u knjižnicu radi nekog naslova uspio taj naslov i posuditi, dok su u nešto manjem broju pokušaja željeni naslov posudili naknadno, uz rezervaciju. Oba odgovora predstavljaju indikator uspjeha rada knjižnice. Korisnici koji su imali negativno iskustvo imali su problema s predugim čekanjem na povrat posuđene knjige, oštećenošću i lošom higijenom, tj. prljavštinom knjige. I u tom segmentu rada knjižnice moguće je zaključiti kako ne postoje veći problemi s kojima su se korisnici susreli prilikom posudbe knjiga. Uvijek postoji mogućnost poboljšavanja segmenta posudbe, ali ta mogućnost ovisi o financijskim sredstvima dodijeljenim knjižnici za nabavu građe općenito.

Četvrto od sedam pitanja odnosilo se na iskustvo prilikom upotrebe usluga u knjižnici. Ispitanicima $(\mathrm{N}=62)$ je bilo ponuđeno pet odgovora i jedna mogućnost samostalnog dopisivanja odgovora. Ispitanici su imali mogućnost odabira više odgovora.

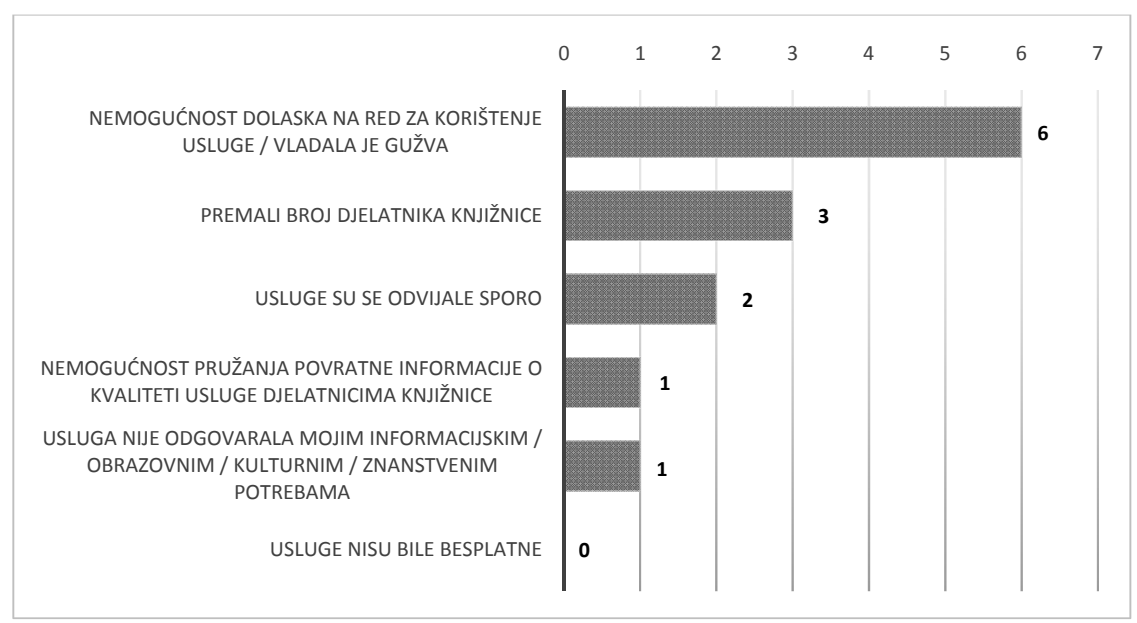

Slika 3. Iskustvo prilikom upotrebe usluga u knjižnici

U ovom pitanju ispitanici su mogli označiti svoja problematična iskustva prilikom upotrebe usluga u knjižnici. Odgovori su bili razvrstani u skupine pozitivnih i negativnih iskustava. U prvoj skupini odgovora 53 ispitanika odgovaraju da su uspješno upotrebljavali sve usluge koje su željeli upotrijebiti. U drugom dijelu ispitanici koji nisu mogli uspješno upotrijebiti usluge knjižnice trebali su odabra- 
ti ponuđene odgovore ili dopisati vlastita negativna iskustva u otvorenom dijelu odgovora. Ispitanici su najčešće odabirali probleme velike gužve u knjižnici, nedostatka dovoljnog broja osoblja i sporog odvijanja usluga. Svi navedeni problemi povezani su s već ranije utvrđenim poteškoćama s kojima se knjižnica susreće, poput nedostatnog prostora, manjka financijskih sredstava i, posljedično, manjeg broja primjeraka građe, a u ovom slučaju i manjeg broja osoblja knjižnice, zbog čega su ispitanici stekli dojam da se knjižnične usluge odvijaju sporo. Problem brzine odvijanja usluga ili gužve moguće je u budućnosti riješiti premještanjem dijela usluga u online okolinu i automatizacijom posudbe i vraćanja knjiga, što je već dugogodišnji slučaj u mnogim europskim i svjetskim knjižnicama. Preostali odgovori svojim brojem nisu utjecali na sliku o knjižnici u ovom pitanju. U otvorenom dijelu pitanja ispitanici su naveli sljedeća problematična iskustva: ,,premalo sjedećih mjesta u čitaonici i prečeste promocije koje ometaju rad“, „Wi-Fi nije radio“, „djelatnici preglasni“.

Peto od ukupno sedam pitanja odnosilo se na razloge doživljenog neuspjeha tijekom posjeta knjižnici. Ispitanicima $(\mathrm{N}=56)$ je bilo ponuđeno trinaest odgovora. Ispitanici su imali mogućnost odabira više odgovora.

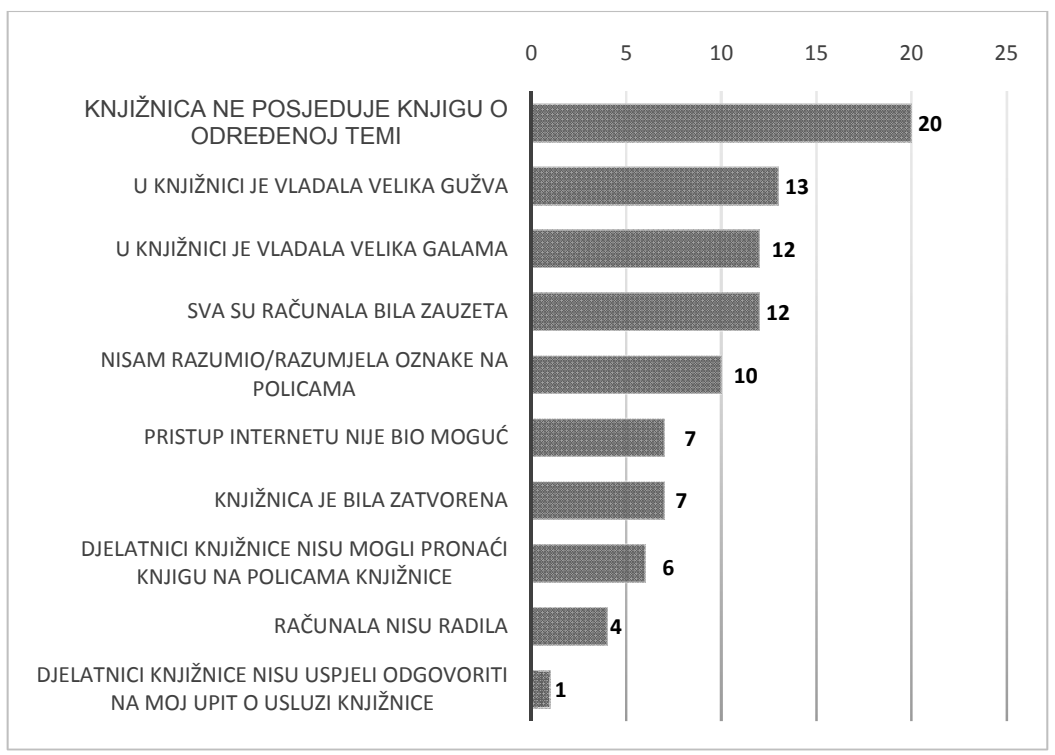

Slika 4. Razlozi neuspjeha upotrebe knjižnice

Na slici 4 navedeni su konkretni razlozi neuspjeha upotrebe knjižnice. U odnosu na prethodno pitanje, koje je bilo usmjereno na cjelokupno iskustvo ispitanika uz poneki odgovor koji su autori ovoga rada smatrali ključnim, u ovom pitanju ponuđen je veći broj odgovora s ciljem dobivanja jasnije slike o razlozima neu- 
spjeha upotrebe knjižnice sa svrhom poboljšanja njezina rada. I u ovom slučaju problemi iskazani u odgovorima koje su odabrali ispitanici ukazuju na temeljne probleme nedostatka prostora i financijskih sredstava za poboljšanje rada knjižnice. Mogućnost posudbe knjige u trenutku kada je ona korisniku potrebna, mirnija radna atmosfera i dovoljan broj računala s pristupom internetu česti su odgovori koji se ponavljaju u više provedenih istraživanja u Knjižnici i čitaonici Bogdana Ogrizovića (Knjižnice grada Zagreba). Manji problemi, poput nemogućnosti pronalaska odgovarajuće police s knjigama zbog oznaka ili nemogućnosti djelatnika da pronađu knjigu ili odgovore na pitanja korisnika, nisu odabrani u većem broju. Odgovor koji se odnosio na radno vrijeme knjižnice zapravo ne bi trebao biti problematičan jer knjižnica radi sedam dana u tjednu.

Šesto pitanje odnosilo se na sudjelovanje u aktivnostima (bez obzira na temu) u knjižnici barem jednom u posljednja 3 mjeseca. Ispitanicima $(\mathrm{N}=45)$ je bilo ponuđeno deset odgovora. Ispitanici su imali mogućnost odabira više odgovora.

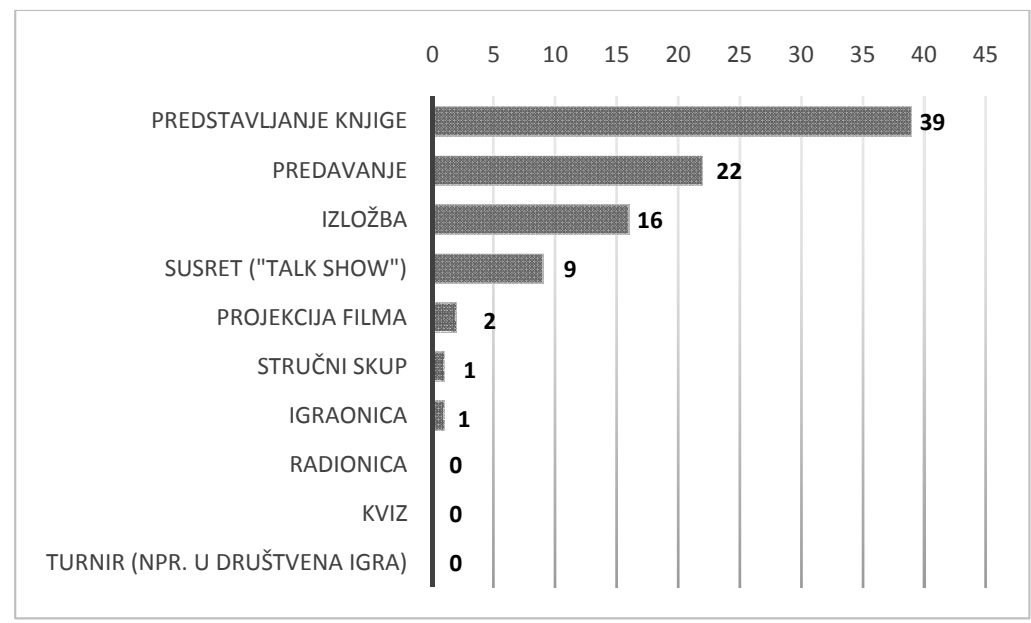

Slika 5. Sudjelovanje u aktivnostima knjižnice barem jednom u tri mjeseca

Na ovo je pitanje odgovorilo manje ispitanika u usporedbi s prethodnim pitanjima. Razlozi mogu biti raznoliki, a s obzirom na prethodno provedena istraživanja u istoj knjižnici, moguće je zaključiti kako su pojedini ispitanici u knjižnicu došli isključivo radi posudbe knjiga, a ne zbog sudjelovanja u aktivnostima koje knjižnica nudi. Vrijedi napomenuti da je za posudbu knjiga potrebno biti članom sustava Knjižnica grada Zagreba, dok za najveći broj aktivnosti ponuđenih u tom pitanju nije potrebno takvo članstvo. Prema dobivenim odgovorima, ispitanici su odabirali aktivnosti po kojima je Knjižnica i čitaonica Bogdana Ogrizovića (Knjižnice grada Zagreba) osobito čuvena u gradu Zagrebu i Hrvatskoj i koje predstav- 
ljaju njezin brend. Stoga su dobiveni odgovori očekivani i oni potvrđuju ispravnu orijentaciju knjižnice prema otvorenosti svim zainteresiranim građanima. Aktivnosti koje nisu odabrane odvijaju se u manjoj mjeri u knjižnici ili ih ispitanici nisu percipirali kao aktivnosti koje su im zanimljive u ovoj knjižnici.

Posljednje od sedam pitanja odnosilo se na prostor knjižnice u kakvom bi ispitanici željeli boraviti. Ispitanicima $(\mathrm{N}=58)$ je ponuđeno devet odgovora, a omogućeno im je i dodavanje vlastitog odgovora. Ispitanici su imali mogućnost odabira više odgovora.

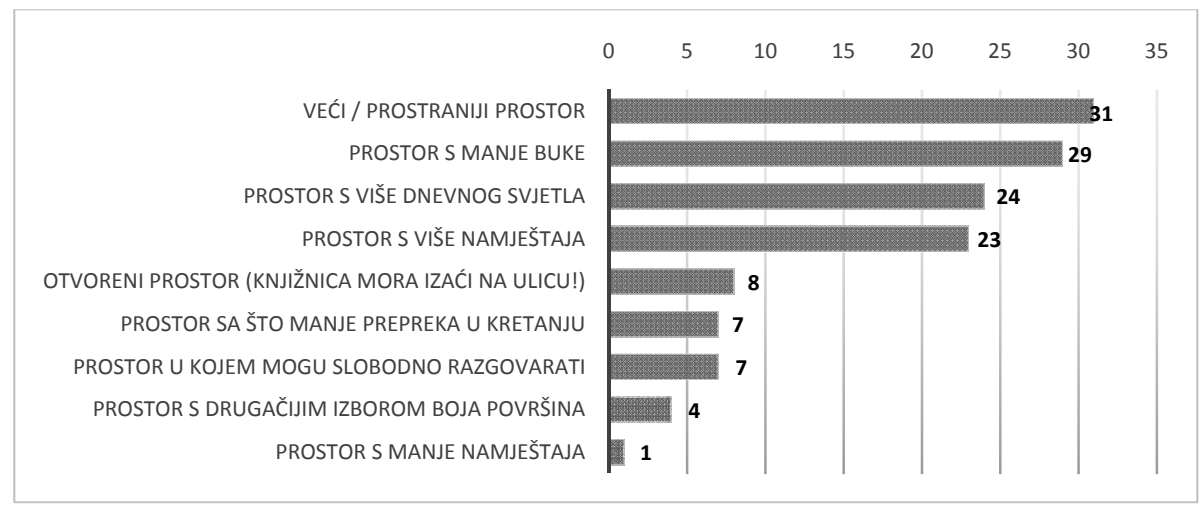

Slika 6. Prostor za boravak korisnika knjižnice

Poput rezultata prethodnih istraživanja, i odgovori na ovo pitanje u aktualnom istraživanju pokazali su da ispitanici žele veći prostor, tišu radnu okolinu i više dnevnog svjetla. Pojedini korisnici žele više namještaja u knjižnici, dok drugi žele manje prepreka, a time i manje namještaja u knjižnici. Prostor knjižnici predstavlja trajan problem zbog nemogućnosti njegova proširenja. Prostor knjižnice nalazi se između prostora drugih privatnih tvrtki i ustanova i prostor za dodatno proširenje zapravo ne postoji. Međutim središnji prostor knjižnice osmišljen je tako da može brzo i fleksibilno odgovoriti na potrebe za organiziranjem drukčijeg rasporeda namještaja ili njegova uklanjanja (osim polica s knjigama), što predstavlja suvremeni pristup organizaciji prostora knjižnice. Knjižnice u današnjem vremenu nemaju mogućnost promjene svojeg ukupnog prostora, ali unutar njega mogu raditi promjene koje su u skladu s njihovim planovima i vizijama. $U$ otvorenom dijelu pitanja ispitanici su dali sljedeće odgovore: „malo više zraka“, ,ponekad malo smetaju predavanja“, „stolne lampe“, „zatvoriti etažu i proširiti prostor čitaonice“, „,bez beskućnika“, „proširenje prostora“. I iz tih je odgovora moguće iščitati postojanje više trajnih problema s kojima se knjižnica suočava u svojem svakodnevnom radu. 


\section{Zaključak}

Narodne knjižnice i dalje imaju važnu ulogu i mjesto u hrvatskom društvu. Kako bi se mogle nastaviti razvijati i nuditi suvremenije usluge i usluge u skladu sa željama korisnika, moraju imati stabilnu financijsku podršku kojom bi mogle osigurati ostvarenje svojih kratkoročnih (jednogodišnjih) i srednjoročnih (višegodišnjih) planova u skladu s razvojem i strategijom sustava u čijem se sastavu nalaze. Istraživanja korisnika sastavni su dio razvoja knjižnica i samo dugoročnom posvećenošću osoblja knjižnice u istraživanju želja i potreba njezinih korisnika knjižnice mogu odgovoriti na njih te učiniti svoju djelatnost i položaj u društvu stabilnijim i boljim. U provedenom istraživanju korisnika ispitanicima je u prvom dijelu dana potpuna sloboda $u$ iskazivanju želja za novinama u svakom aspektu rada knjižnice, što za njih nije bio jednostavan zadatak. Korisnici su u najvećoj mjeri svoje želje usmjerili prema proširivanju ili barem reorganizaciji postojećeg prostora knjižnice. Dok je za prvu aktivnost već navedeno kako nije moguća, druga aktivnost provodi se u knjižnici u skladu s njezinim planovima i mogućnostima. U budućnosti je potrebno voditi računa u mogućnosti nabave fleksibilnijeg namještaja koji je moguće sklopiti i rasklopiti, jednostavnije postaviti u prostor ili ukloniti. Preostale želje u najvećem su se broju odnosile na što bogatiju, raznovrsniju i brojniju građu, veći broj računala i pristup internetu te e-građu koje kronično nedostaje na hrvatskom knjižarskom tržištu, a samim time i u knjižnicama. Sve navedeno potrebno je uzeti u obzir prilikom planiranja budućih proračuna knjižnice i njezinih aktivnosti. Odgovori ispitanika u drugom dijelu anketnog upitnika samo su potvrdili njihove želje iz prvog dijela i ujedno su omogućili detaljniji i konkretniji uvid u probleme s kojima su se ispitanici susreli prilikom boravka u knjižnici. Mišljenje ispitanika koji su ujedno i korisnici knjižnice (uz članstvo ili bez njega) važno je za položaj knjižnice u društvu, njezinu prepoznatljivost $\mathrm{i}$ kvalitetu rada te je svaki odgovor potrebno razmotriti i vidjeti mogu li se napraviti odgovarajuće promjene u sustavu organizacije prostora knjižnice, posudbe građe, upotrebe građe u prostoru knjižnice te organizaciji aktivnosti u središnjem prostoru knjižnice koje ponekad znaju zasmetati dijelu korisnika. Dio aktivnosti knjižnice bit će moguće premjestiti u online okolinu, ali najveća kvaliteta rada knjižnice proizlazi iz interakcije korisnika knjižnice s osobljem i drugim korisnicima knjižnice u njezinu fizičkom prostoru. Sveukupno, i ovo je istraživanje korisnika pokazalo kako korisnici nisu samo statistički pokazatelj u godišnjem izvještaju knjižnice, već predstavljaju važan čimbenik u oblikovanju budućnosti knjižnice koja se nalazi pred novim izazovima, ali i novim mogućnostima oblikovanja usluga i novih uloga u korisničkoj zajednici. 


\section{LITERATURA}

Ahmad, Z. Library 2.0: the 21st century Web based library services. // Gyankosh: The Journal of Library \& Information Management 4, 2(2013), 28-32.

Cheryl S.; K. Roberts; K. Haycock. The role of influence in city and public library partnerships: an exploratory study. // Library Management 35, 3(2014), 213-223.

Haycock, K. Exemplary public library branch managers: their characteristics and effectiveness. // Library Management 32, 4/5(2011), 266-278.

Henczel, S. Measuring and evaluating the library's contribution to organisational success: developing a strategic measurement model. // Performance Measurement and Metrics 7, 1(2006), 7-16.

Hiller, S.; M. Kyrillidou; J. Self. When the evidence is not enough: organizational factors that influence effective and successful library assessment. // Performance Measurement and Metrics 9, 3(2008), 223-230.

Podbrežnik, I. Ugotavljanje zadovoljstva uporabnikov s kakovostjo storitev v slovenski splošni knjižnici. // Knjižnica 60, 1(2016), 17-44.

Proffitt, M.; J. Michalko; M. Renspie. Shaping the library to the life of the users: adapting, empowering, partnering, engaging. Dublin, Ohio: OCLC, 2015.

Rogers, R. D.; D. C. Weber. University library administration, New York : H.W. Wilson Company, 1971.

Rowley, J. Should your library have an innovation strategy? // Library Management 32, 4/5(2011), 251-265.

Seal, R. A. Library spaces in the 21st century: meeting the challenges of user needs for information, technology, and expertise. // Library Management 36, 8/9(2015), 558-569.

Urquhart, C.; J. Turner. Reflections on the value and impact of library andinformation services. Part 2: impact assessment. // Performance Measurement and Metrics 17, 1(2016), 5-28.

Vrana, R.; J. Kovačević. Istraživanje korisnika u knjižnicama: temelj razvoja knjižnica. // Svezak: časopis Društva knjižničara Bilogore, Podravine i Kalničkog prigorja 17(2015), 9.

Vrana, R.; J. Kovačević. Razvoj knjižničnih zbirki kao preduvjet i mjera razvoja knjižnice. // Vjesnik bibliotekara Hrvatske 60, 1(2017), 79-102.

Vrana, R.; J. Kovačević. Pogled na knjižnične usluge iz perspektive korisnika. // Vjesnik bibliotekara Hrvatske 58, 1-2(2015), 135-160.

Vrana, R.; J. Kovačević. Percepcija korisnika o knjižnici i knjižničnim uslugama kao temelj marketinške strategije knjižnice. // Vjesnik bibliotekara Hrvatske 56, 3(2013), 23-46.

Vrana, R.; J. Kovačević. Položaj knjižnice u umreženom društvu. // Vjesnik bibliotekara Hrvatske 53, 3-4(2010), 25-41. 


\section{PRILOG 1. \\ ŽELJE KORISNIKA KNJIŽNICA GRUPIRANE PREMA SRODNOSTI ODGOVORA}

\section{Tablica 1. Prostor}

\begin{tabular}{|l|l|}
\hline Prostor & Dovoljno mjesta za učenje \\
\hline Više mjesta za sjedenje & $\begin{array}{l}\text { Urediti/proširiti sanitarne prostorije za } \\
\text { korisnike (pa i uz naplatu upotrebe) }\end{array}$ \\
\hline Veći glazbeni odjel & $\begin{array}{l}\text { Vidjeti više izložbi, tj. da su slike izložene } \\
\text { kroz cijeli prostor knjižnice }\end{array}$ \\
\hline $\begin{array}{l}\text { Multimedijalni centar (prostor za } \\
\text { slušanje glazbe i gledanje filmova) }\end{array}$ & $\begin{array}{l}\text { Više dnevnog svjetla, fotelje za ugodnije } \\
\text { čitanje }\end{array}$ \\
\hline Dnevni boravak za djecu i mlade & $\begin{array}{l}\text { Udobne fotelje po uzoru na one u } \\
\text { knjižnici Glazbene akademije }\end{array}$ \\
\hline Veći prostor za učenje & Veći prostori čitaonice \\
\hline Više prostorâ za učenje & Više prostora za rad \\
\hline $\begin{array}{l}\text { Zatvoriti otvor na gornjoj etaži } \\
\text { nosivom konstrukcijom i proširiti } \\
\text { prostor knjižnice/čitaonice }\end{array}$ & Kutak za tinejdžere \\
\hline Udobno mjesto za čitanje & Knjižnica odgovara prostorom i uslugama \\
\hline $\begin{array}{l}\text { Poseban dio za učenje - da se u } \\
\text { istom prostoru ne održava nikakvo } \\
\text { predavanje }\end{array}$ & Više boja \\
\hline Odjeljci za računala & Više mjesta samo za čitanje \\
\hline Prostor za grupno učenje i rad & Prostrani stolovi
\end{tabular}

Tablica 2. Navigacija prostorom

\section{Navigacija prostorom}

Mapa za lakše snalaženje (označene sve police, oznake na njima) 
Tablica 3. Radno vrijeme

Radno vrijeme

Ljetno radno vrijeme - suprotna smjena s A. Starčević

Dulje radno vrijeme prostora za učenje

Tablica 4. Usluge

Usluge

Mogućnost posudbe e-knjiga

Aplikacija koja omogućuje provjeru raspoloživosti naslova

Organizacija razmjene knjiga između članova

Dnevne novosti

Tablica 5. Građa

\begin{tabular}{|l|l|}
\hline Građa & Nova izdanja DVD-a \\
\hline Raznovrsnost naslova & $\begin{array}{l}\text { E-knjige (odgovor koji se ponavlja više } \\
\text { puta) }\end{array}$ \\
\hline $\begin{array}{l}\text { Da ima što više knjiga (odgovor koji se } \\
\text { ponavlja više puta) }\end{array}$ & Dnevne novine \\
\hline $\begin{array}{l}\text { Audioknjige (slično kao u SAD-u s } \\
\text { overdriveom - odgovor koji se ponavlja } \\
\text { više puta) }\end{array}$ & Prodaja vlastitih knjiga knjižnici \\
\hline Novi naslovi svjetske književnosti & Noviji naslovi \\
\hline Kupnja dotrajalih knjiga od knjižnice & Više prijevoda stranih autora \\
\hline Strana literatura & $\begin{array}{l}\text { Više naslova na stranim jezicima (iako } \\
\text { Knjižnica B. Ogrizovića, za razliku od } \\
\text { drugih, raspolaže pristojnim fondom) }\end{array}$ \\
\hline Strani časopisi & Snimke baleta/opera \\
\hline Više primjeraka istog naslova & Klasična glazba (audiozapisi) \\
\hline Više udžbenika za medicinski fakultet & Više novijih knjiga na stranim jezicima \\
\hline Notni zapisi za glazbu (napose „klasični“ & Više stripova \\
\hline $\begin{array}{l}\text { Više knjiga iz područja stručne literature } \\
\text { (popularnoznanstvene knjige) }\end{array}$ & \\
\hline Redovni naslovi &
\end{tabular}


Tablica 6. Buka

\begin{tabular}{|l|}
\hline Buka \\
\hline Poseban dio za učenje - da u istom prostoru nije nikakvo predavanje \\
\hline Tihi prostor za učenje \\
\hline Manja gužva i buka \\
\hline
\end{tabular}

Tablica 7. Zrak

\begin{tabular}{|l|l|}
\hline Zrak \\
\hline Bolji klimatizacijski uređaj & \\
\hline
\end{tabular}

Tablica 8. Informacijska i komunikacijska tehnologija

\begin{tabular}{|l|l|l|}
\hline IT & $\begin{array}{l}\text { Internet prihvatljiv za } \\
\text { umirovljenike }\end{array}$ & $\begin{array}{l}\text { Računala s pristupom } \\
\text { internetu }\end{array}$ \\
\hline $\begin{array}{l}\text { Računala s pristupom stručnim } \\
\text { stranicama (up to date) }\end{array}$ & $\begin{array}{l}\text { Bolji Wi-Fi (odgovor se } \\
\text { ponavlja više puta) }\end{array}$ & Laptopi \\
\hline $\begin{array}{l}\text { Više računala (odgovor se } \\
\text { ponavlja više puta) }\end{array}$ & $\begin{array}{l}\text { Aplikacija s } \\
\text { događanjima u } \\
\text { knjižnici }\end{array}$ & $\begin{array}{l}\text { Touch screen } \\
\text { informacijski pult }\end{array}$ \\
\hline
\end{tabular}

\section{Tablica 9. Aktivnosti}

\begin{tabular}{|c|c|c|}
\hline \multicolumn{3}{|l|}{ Aktivnosti } \\
\hline \multicolumn{2}{|c|}{\begin{tabular}{l|l} 
Manje promocija (odgovor & lzložbe \\
se ponavlja više puta) &
\end{tabular}} & \\
\hline Druženja do 7 ujutro & $\begin{array}{l}\text { Kreativne radionice / } \\
\text { književni klubovi }\end{array}$ & $\begin{array}{l}\text { Projekcije filmova iz } \\
\text { različitih područja (znanosti, } \\
\text { umjetnosti itd.) uz stručnog } \\
\text { voditelja }\end{array}$ \\
\hline Komorni koncerti (gitara) & $\begin{array}{l}\text { Predavanja o prehrani } \\
\text { djece (zašto djeca } \\
\text { odbijaju hranu?) }\end{array}$ & Radionice pisanja \\
\hline $\begin{array}{l}\text { Više radionica/predavanja } \\
\text { namijenjenih studentima }\end{array}$ & $\begin{array}{l}\text { Zanimljivija } \\
\text { predavanja }\end{array}$ & Prezentacije knjiga \\
\hline
\end{tabular}


Vjesnik bibliotekara Hrvatske 61, 2(2018), 47-71

\begin{tabular}{|l|l|l|}
\hline Aktivnosti & Autogeni trening & $\begin{array}{l}\text { Projekcije starih filmova i } \\
\text { filmova mladih redatelja }\end{array}$ \\
\hline Astrolog & Više filmova & Kvalitetnije promocije \\
\hline Miniknjižara & Razne radionice & Česti gosti pisci \\
\hline Edukacija starijih osoba & $\begin{array}{l}\text { Književni klub za } \\
\text { srednjoškolce }\end{array}$ & $\begin{array}{l}\text { Radionice o pisanju (romana, } \\
\text { eseja...) }\end{array}$ \\
\hline $\begin{array}{l}\text { Gostovanja pojedinih } \\
\text { političara }\end{array}$ & Manje predavanja \\
\hline Više stručnih predavanja & Manje tribina & \\
\hline
\end{tabular}

\section{Tablica 10. Ostalo}

\begin{tabular}{|l|l|l|}
\hline \multicolumn{2}{|l|}{ Ostalo } \\
\hline $\begin{array}{l}\text { Više vješalica (stalaka za } \\
\text { odlaganje kaputa, jakni, } \\
\text { kišobrana) }\end{array}$ & $\begin{array}{l}\text { Zadovoljni } \\
\text { korisnici (uvijek) }\end{array}$ & $\begin{array}{l}\text { Koncept je super, samo bez } \\
\text { npr. prosjaka koji kopaju po } \\
\text { smeću knjižnice, sjede na podu } \\
\text { ili žicaju korisnike }\end{array}$ \\
\hline $\begin{array}{l}\text { Informacije za honorarne } \\
\text { poslove (područje kulture, } \\
\text { turizma, obrazovanja...) }\end{array}$ & Pribor za pisanje & \\
\hline
\end{tabular}




\section{PRILOG 2. ANKETNI UPITNIK \\ KAKVU KNJIŽNICU ŽELITE?}

1. Navedite TRI ŽELJE KOJE SE ODNOSE NA BILO ŠTO što biste ŽELJELI vidjeti ili upotrijebiti u knjižnici:

1.

2.

3.

2. Prema Vašem mišljenju, što knjižnica mora pružiti korisniku (ZA SVAKI PONUĐENI ODGOVOR OZNAČITE OCJENU VAŽNOSTI TOGA ODGOVORA ZA VAS: 1 - najmanje važno, 5 - najvažnije)?

\begin{tabular}{|c|c|c|c|c|c|}
\hline & 1 & 2 & 3 & 4 & 5 \\
\hline \multicolumn{6}{|l|}{ Prostor za susrete } \\
\hline \multicolumn{6}{|l|}{ Besplatne (sve) usluge } \\
\hline \multicolumn{6}{|l|}{$\begin{array}{l}\text { Besplatno sudjelovanje u događajima koji se } \\
\text { odvijaju u knjižnici }\end{array}$} \\
\hline \multicolumn{6}{|l|}{ Izvore informacija potrebne za pronalaženje posla } \\
\hline \multicolumn{6}{|l|}{$\begin{array}{l}\text { Izvore informacija potrebne za obrazovanje (bez } \\
\text { obzira na njegovu vrstu) }\end{array}$} \\
\hline \multicolumn{6}{|l|}{$\begin{array}{l}\text { Izvore informacija potrebne za znanstvena } \\
\text { istraživanja }\end{array}$} \\
\hline \multicolumn{6}{|l|}{ Aktivnosti za djecu } \\
\hline \multicolumn{6}{|l|}{ Aktivnosti za tinejdžere } \\
\hline \multicolumn{6}{|l|}{ Aktivnosti za odrasle } \\
\hline \multicolumn{6}{|l|}{ Tihi prostor za učenje } \\
\hline \multicolumn{6}{|l|}{$\begin{array}{l}\text { Tihi prostor za čitanje novina i časopisa (tiskanih i } \\
\text { digitalnih) }\end{array}$} \\
\hline \multicolumn{6}{|l|}{ Bežični pristup internetu (Wi-Fi) } \\
\hline \multicolumn{6}{|l|}{$\begin{array}{l}\text { Uspješnu posudbu knjiga svaki put (veći broj } \\
\text { primjeraka istoga naslova knjige) }\end{array}$} \\
\hline \multicolumn{6}{|l|}{$\begin{array}{l}\text { Posudbu e-knjiga (putem mrežne stranice } \\
\text { knjižnice) }\end{array}$} \\
\hline \multicolumn{6}{|l|}{$\begin{array}{l}\text { Pomoć knjižničara u upotrebi bilo kojeg segmenta } \\
\text { rada knjižnice }\end{array}$} \\
\hline \multicolumn{6}{|l|}{$\begin{array}{l}\text { Aplikaciju za mobilni telefon za interakciju } \\
\text { korisnika s knjižnicom }\end{array}$} \\
\hline \multicolumn{6}{|l|}{$\begin{array}{l}\text { Web stranicu knjižnice za interakciju korisnika s } \\
\text { knjižnicom }\end{array}$} \\
\hline \multicolumn{6}{|l|}{$\begin{array}{l}\text { Prilagođeno radno vrijeme - ljetno (skraćeno/ } \\
\text { dvokratno) i zimsko (cijeli dan) }\end{array}$} \\
\hline \multicolumn{6}{|l|}{ Mogućnost predlaganja novih usluga knjižnici } \\
\hline $\begin{array}{l}\text { Mogućnost predlaganja novih naslova knjiga, } \\
\text { časopisa i novina knjižnici }\end{array}$ & & & & & \\
\hline
\end{tabular}


3. Kakvo je bilo Vaše iskustvo u kontaktu s djelatnicima knjižnice (MOGUĆE JE OZNAČITI VIŠE ODGOVORA)?
a) Demonstrirali su znanje
b) Bili su spremni na pružanje pomoći o građi i uslugama knjižnice
c) Bili su ljubazni
d) Bili su komunikativni
e) Bili su brzi u reagiranju na upit/zahtjev za građom ili uslugom knjižnice
f) Imali ste drukčije iskustvo, navedite kakvo:

4. Kakvo je bilo Vaše iskustvo prilikom posudbe knjiga u ovoj knjižnici (MOGUĆE JE OZNAČITI VIŠE ODGOVORA)?
a) Posudio/la sam željenu knjigu u prvom pokušaju prilikom dolaska u knjižnicu
b) Posudio/la sam željenu knjigu nedugo nakon prvog pokušaja posudbe (uz pret- hodnu rezervaciju knjige)
c) Vrijeme od rezervacije do mogućnosti posudbe knjige bilo je predugo
d) Posuđena knjiga bila je oštećena
e) Posuđena knjiga bila je prljava
f) Imali ste drukčije iskustvo, navedite kakvo:

5. Kakvo je bilo Vaše iskustvo prilikom upotrebe usluga u ovoj knjižnici (MOGUĆE JE OZNAČITI VIŠE ODGOVORA)?
a) Uspješno sam upotrijebio/upotrijebila sve usluge koje sam želio/željela upo- trijebiti
b) Dio usluga koje sam želio/željela upotrijebiti ipak nisam uspio/uspjela upotri- jebiti zbog (odaberite razlog):
a. Usluge nisu bile besplatne
b. Usluge su se odvijale sporo
c. Premalog broja djelatnika knjižnice
d. Nemogućnosti pružanja povratne informacije o kvaliteti usluge djelatni- cima knjižnice
e. Nemogućnosti dolaska na red za upotrebu usluge / vladala je gužva
f. Usluga nije odgovarala mojim informacijskim/obrazovnim/kulturnim/
c) Imali ste drukčije iskustvo, navedite kakvo:

6. Općenito, ukoliko ste doživjeli neuspjeh tijekom posjeta knjižnici, označite razloge za to (MOGUĆE JE OZNAČITI VIŠE ODGOVORA):
a) Knjiga je bila posuđena
b) Nemogućnost upotrebe usluge
c) Knjižnica ne posjeduje knjigu o određenoj temi koja me zanima 
d) Nisam mogao/la pronaći knjigu na policama knjižnice jer nisam razumio/la oznake na policama

e) Djelatnici knjižnice nisu mogli pronaći knjigu na policama knjižnice

f) Djelatnici knjižnice nisu uspjeli odgovoriti na moj upit o usluzi knjižnice

g) Djelatnici knjižnice nisu uspjeli odgovoriti na moj upit (tražio/la sam općenite informacije)

h) Računala nisu radila

i) Sva su računala bila zauzeta

j) Pristup internetu nije bio moguć

k) Knjižnica je bila zatvorena

1) U knjižnici je vladala velika gužva

m) U knjižnici je vladala velika galama

7. U kojim ste aktivnostima (bez obzira na temu) u knjižnici sudjelovali barem jednom u posljednja 3 mjeseca (MOGUĆE JE OZNAČITI VIŠE ODGOVORA)?
a) Izložbi
b) Predstavljanju knjige
c) Susretu (talk showu)
d) Radionici
e) Igraonici
f) Predavanju
g) Kvizu
h) Projekciji filma
i) Stručnom skupu
j) Turniru (npr. u društvenoj igri)

8. U kakvom biste prostoru knjižnice željeli boraviti (MOGUĆE JE OZNAČITI VIŠE ODGOVORA)?
a) U većem/prostranijem prostoru
b) U prostoru s manje namještaja (stolica, fotelja, polica)
c) U prostoru s više namještaja (stolica, fotelja, polica)
d) U prostoru s (općenito) što manje prepreka u kretanju
e) U prostoru s više dnevnog svjetla
f) U prostoru s drukčijim izborom boja površina (zidova, podova)
g) U prostoru s manje buke
h) U prostoru u kojem mogu slobodno (glasno, ali ne preglasno) razgovarati
i) U otvorenom prostoru (knjižnica mora izaći na ulicu!)
j) Imate neku drugi zamisao, napišite kakvu: 
